\title{
A management plan for a declining population of the Souss valley tortoise in an arid steppe-land of west-central Morocco
}

\author{
Nawal Hichami ${ }^{1,2}$, Mohammed Znari2,3,* \\ ${ }^{1}$ Laboratory of Biotechnology \& Sustainable Development of Natural Resources, Polydisciplinary Faculty \\ of Beni Mellal, Sultan Moulay Slimane University. Mghila PO Box. 592, Beni Mellal 23000, Morocco. \\ ${ }^{2}$ Laboratory "Water, Biodiversity \& Climate Change", Department of Biology, Faculty of Science, Semlalia, \\ Cadi Ayyad University, Bd Prince Moulay Abdellah. PO Box 2390, 40000 Marrakech, Morocco. \\ ${ }^{3}$ Natural History Museum of Marrakech, Cadi Ayyad University, Ave Allal El Fassi. PO Box 550, 40000 \\ Marrakech, Morocco. \\ *Correspondence: znarim@gmail.com
}

Received: 14 April 2020; returned for review: 29 July 2020; accepted 25 May 2021.

The endangered Moorish tortoise Testudo graeca is the unique terrestrial chelonian species in Northwest Africa. In west-central Morocco, the endemic subspecies, the Souss valley tortoise T. g. soussensis, occupies semi-arid to arid low-quality habitats, and is subject to serious threats. A long-term mark-recapture programme from 2001 to 2012 allowed estimating population size and structure, sex ratio, and survivorship in one of the well-known populations in a degraded and overgrazed arid steppe-land of westcentral Morocco. Spring population size considerably decreased to more than half in less than 10 years, with a mean density lower than 3 ind.ha ${ }^{-1}$ in 2012 compared to its last known density estimated in 2003. In spring 2012, the population structure exhibited an unbalanced male-biased sex ratio (61:39) and a scarcity of juveniles $(<5 \%)$. We identified five major conservation problems in the study area: (i) habitat destruction and overgrazing; (ii) over-collecting of tortoises for pet trade , iii) direct disturbance; iv) tortoise handling mostly for field research, and v) increased extinction risk due to the small population size. We carried out a population viability analysis using the VORTEX software based on published and obtained data on population and life history parameters. With no management action, the population will go extinct during the forthcoming 40 years after the last estimate. The most efficient management option for a long-term persistence of the population would be reducing the nest and neonate mortality by $90 \%$. To attenuate the impact of the threatening factors, we developed a management plan that includes population reinforcement and habitat restoration options.

Key words: arid steppes; management plan; population characteristics; population viability; Souss valley tortoise; threats.

Tortoises show a relatively long reproductive lifespan, a delayed maturity, and a low hatching success and juvenile survivorship. These demographic traits make tortoise's populations particularly sensitive to the loss of mature individuals. Terrestrial chelonians are often threatened by human activity, such as pet trade, hunting for food, or habitat destruction (VAN AвbEMA, 1997) resulting in a strong decline of many local populations. During the last decades, numerous management plans have been implemented for numerous tortoise species. For instance, BoARMAN (2003) and DoAk et al. (1997), studied the management strategies for declining desert 
tortoises (Gopherus agassizii) populations in the Mojave Desert, California (USA), through reducing common raven predation and human disturbance in concert with actions that reduce other causes of desert tortoise mortality to aid the longterm recovery of their populations.

The Moorish tortoise Testudo graeca (L., 1758) is considered as one of the most charismatic species of the circumMediterranean fauna. However, this species is endangered across its entire range (classified, as vulnerable (VU) by IUCN (2018)) and the main threats are habitat loss (IUCN, 2018) and collection for pet trade (Lambert, 1979; ZnARI et al., 2005; Pérez et al., 2011). Testudo graeca from North Africa, Greece and Spain is a typical example of this general trend (ERNST \& Barbour, 1989; Iverson, 1992). Although inadequately quantified, all experts agree that populations are declining markedly in almost all areas (Stubbs, 1989; LAMBERT, 1995). In this context, precise information on the demographic characteristics and vulnerability of populations are urgently required to eventually sound the emergency alarm and to set up conservation and management plans. We particularly need to better understand the proximate causes of such decline. Unfortunately, our current knowledge on the population ecology and long-term demographic variations of this species is very limited. For example, intensive studies have been conducted on very few populations, notably in Southern Spain (ANdreu, 1987; Keller, 1993; DiazPaniagua et al., 1995, 1996, 1997; Keller et al., 1998; ANDreu et al., 2000) and Greece (Hailey 1988; Hailey et al., 1988, 1990, 2000). In North Africa, there are a few de- mographic studies on T. graeca in Morocco (LAMBert 1969, 1981, 1982; Bayley \& HighFIELD, 1996; El Mouden et al., 2002; SlimaNi et al., 2002; Ben Kaddour et al., 2006) and Algeria (RouAg et al., 2007). The loss of suitable habitats for this species in the region (mostly due to overgrazing) is particularly important and tends to increase over time (Quézel, 2002).

The Souss valley tortoise, $T . g$. soussensis, an endemic subspecies to westcentral Morocco, inhabits arid areas of low quality (ANADon et al., 2012), mostly in the Souss valley, the Atlantic coastal area of Essaouira and the inland arid-steppes of the Haouz plain and central Jbilet Mountains around the Marrakech city (ZNARI \& Hichami, 2018). This endemic tortoise has been qualified as a strict semiarid taxon since the probability of its occurrence plums between 300 and $400 \mathrm{~mm}$ of annual rainfall (Anadon et al., 2015). Preliminary surveys indicated a considerable regression of the population of this subspecies in these latter areas. Such a regression is presumably due to a combination of unfavorable climatic conditions (chronic droughts), excessive urbanization and pet trade in these touristic abovementioned locations during the previous two decades. In spring 2003, Ben Kaddour et al. (2006) reported in an arid and overgrazed steppe area close to Marrakech city, westcentral Morocco, a relatively high local population density of around 6 ind./ha (nearly 200 individuals concentrated within a central 33-ha area).

Even though this species is protected from over-collection, many shops in Marrakech showed hundreds of tortoises for sale (ZNARI et al., 2005). Most (65.5\%) of 
these tortoises were small sized $(\mathrm{SCL}<100$ $\mathrm{mm}$ ), and were likely young (immature) tortoises (age: from 2 to 9 years). In addition, its natural habitat is strongly degraded due to overgrazing along with cutting of Spiny jujube (Ziziphus lotus) bushes that are used both as thermal refuges and as a good supply of "pantry food" (LAgarde et al., 2012).

Moreover, the climate change that the Marrakech area has been experiencing during the last decades (Ait Brahim et al., 2017), would have undoubtedly affected the steppe-lands and their wildlife, including tortoises. Indeed, and according to Ait BRAHIM et al. (2017), in the arid area of Marrakech climate has changed during the last decades (since 1961) with a global warming reaching $+1.5^{\circ} \mathrm{C}$, but a decrease in annual rainfall of more than $22 \%$. In addition, there was an increase in frequency and intensity of drought periods. An evolutionary trend towards drought in Marrakech is clearly noticeable, because the occurrence of droughts became increasingly more frequent after 1980, especially in Marrakech. This observation demonstrates longer periods of intraannual drought and therefore an increase of their persistence time. Hence, the increase of droughts is anticipated in the area (Ait BRAHIm et al., 2017).

We predict that, due to climate change stress (drought) and human pressures, this population has declined with a potential mid- to long-term extinction risk. The present study is aimed at obtaining basic demographic data for a population viability analysis and for establishing conservation and restoration guidelines. We developed a management plan to allow the long-term (i.e., 100 years) survival of T. g. soussensis in arid steppe-lands in the Jbilet mountains, west-central Morocco.

\section{Materials and Methods}

\section{Study site}

The study area is located in the central Jbilet Mountains about $25 \mathrm{Km}$ north to Marrakech, west-central Morocco (31 $37^{\prime} \mathrm{N}, 8^{\circ} 02^{\prime} \mathrm{W}$; and average of $580 \mathrm{~m}$ a.s.l.). The region is arid, with a mean annual rainfall of $240 \mathrm{~mm}$, occurring mostly between September and February (EL Mouden et al., 1999; ZnARI et al., 2002). Average air temperature in the hottest month (July) is $39^{\circ} \mathrm{C}$ and the minimal annual temperature (January) is normally around $0^{\circ} \mathrm{C}$ (Le Houérou, 1989; Emberger, 1933). Plant cover consists mainly of Jujube bushes (Ziziphus lotus), with some widely scattered Morocco-gum (Vachellia gummifera) and bridal broom (Retama monosper$m a)$. Most of the habitat is open, hard bare ground with stony soil on the flat and low hillsides that surround small sandy, pebbly or stony wadies (small rivers). Seasonal over-grazing by domestic livestock (sheep and goats) strongly affects the vegetation. A simple visual inspection of the study area reveals two major and different plant assemblages: a relatively rich and diversified plant community under Jujube, protected against over-grazing by the spiny structure of this shrub, and a less diversified plant community out of the Jujube, with a very scattered plant cover (see El Mouden et al., 2005).

\section{Sampling methodology}

In order to estimate the mean annual adult survival rate over at least one gener- 
ation, we conducted a long-term multiple mark-recapture sampling from 2001 to 2012; we intensively captured tortoises once every spring during 3 to 5 consecutive days. In 2012, we carried out a short multiple mark-recapture biweekly series from late February to mid-May to assess the spring final population size. We referred to the first initial population size estimate obtained in spring 2003 for the same population as in Ben Kaddour et al. (2005) to highlight its demographic trend. We established the mean population structure from year-round sampling during 27 to 43 days per year in 2011 and 2012. We compared the obtained structure to those reported for the same population in 2001 (ZnARi et al., 2005) and 2003 (Ben Kaddour et al., 2005).

Tortoises were caught by hand, sexed (based on morphological sexual dimorphism traits as in CARretero et al., 2005; ZnARI \& Hichami, 2018), weighed (to the nearest $0.1 \mathrm{~g}$ ), measured with a caliper for carapace length (CL), width (CW) and height $(\mathrm{CH})$ (to the nearest $0.1 \mathrm{~mm}$ ), and individually marked with notches on their marginal scutes according to a numerical combination code. The individual age was estimated from the number of annuli on the costal scutes (ZNARI et al., 2005).

\section{Data analyses}

We developed a management plan using a conceptual model according to Sutherland's approach (Sutherland, 1996). Briefly, we tried to identify the major factors that might hamper the long-term population persistence (over 100 years), defined the causes of the main acting factors, and assessed possible measures to keep their impacts to a minimal level.

We used Vortex 9.99 (Miller \& Lacy, 2005) to simulate the viability of the studied population. We used data obtained from our fieldwork (current population size, survival rate, sex ratio, clutch size, age at sexual maturity, age structure) and from other published studies (Doñana National Park in Andreu, 1987; Keller 1993; Diaz-Paniagua et al., 1995, 1996, 1997; KelLER et al., 1998; ANDREu et al., 2000) such as initial population size, percent of breeding females annually, maximum reproduction age, and juvenile's survival rates (Table 1). We used MARK 8.0 (Соoch \& White, 2017) for estimating the survival rates from the mark-recapture histories of 233 males and 264 females (2001-2012). Given the small number $(n=29)$ of marked juveniles, these were excluded from the analyses.

We derived the parameter estimates from a model where the recapture rate was constant over time and similar for all tortoises (i.e., a single recapture parameter was estimated for both males and females). Survival rate did not vary over the years but was different between sexes (model Phi(g) p(.); Lebreton et al., (1992)). For an approximation of environmental variation (EV) in survival, we estimated survival rate from a model with temporal variation in this parameter but no effect of group (model Phi(t) $\mathrm{p}($.$) ). We evaluated,$ from the Box D in the Vortex manual (Miller \& LaCy, 2005), that EV was less than $1 \%$, which was considered as a conservative estimation in the simulations. Accurate information on many population parameter estimates in tortoises are lacking (Shine \& Iverson, 1995), making it difficult 
Table 1: Values of population parameters entered into the population viability analyses using the Vortex software (Miller \& LACY, 2005).

\begin{tabular}{|c|c|c|}
\hline Parameter & Basic scenarios & References \\
\hline Carrying capacity (K) & 192 & Ben Kaddour, 2003 \\
\hline N initial & 88 & Estimated from mark-recapture data. \\
\hline Hatching success & $82.4 \%$ & Diaz-PANiagua et al., 1997 (Doñana) \\
\hline $\begin{array}{l}\text { Structure of population in } 2012 \\
\text { (Spring) }\end{array}$ & $\begin{array}{l}\text { Of } 0 \text { to } 6 \text { years: } 5.06 \% \\
\text { Adult male de } 7 \text { years and up: } 58.23 \% \\
\text { Adult females of } 9 \text { years and up: } 36.71 \%\end{array}$ & \\
\hline \multicolumn{3}{|l|}{ Age-specific mortality } \\
\hline Females & $\begin{array}{l}\text { 0-6years: } 98.7-90,3 \%(94.5 \%) \text { per year } \\
0-6 \text { years: } 98.7-90.3 \%(91 \%) \text { per year } \\
11 \text { years and up } 19 \% \text { / years, DS: } 1 \%\end{array}$ & $\begin{array}{l}\text { DiAz-PANiAgua et al., } 2001 \\
\text { BALLESTAR et al., } 2004 \\
\text { Present study, estimated from mark- } \\
\text { recapture data. Age at sexual maturity } \\
\text { from ZnARI et al. (2005) }\end{array}$ \\
\hline Males & $\begin{array}{l}0-6 \text { years: } 98.7-90.3 \%(94.5 \%) \text { per year } \\
0-6 \text { years: } 98.7-90.3 \%(91 \%) \text { per year } \\
8 \text { years and up } 14 \% \text { / years, DS: } 1 \%\end{array}$ & $\begin{array}{l}\text { DiAz-PANiAgua et al., } 2001 \\
\text { BALLESTAR et al., } 2004 \\
\text { Present study, estimated from mark- } \\
\text { recapture data. Age at sexual maturity } \\
\text { from ZnARI et al. (2005) }\end{array}$ \\
\hline Inbreeding & No & \\
\hline $\begin{array}{l}\text { Correlation Environmental Variation } \\
\text { (EV) (reproduction) - EV (survival) }\end{array}$ & Yes & $\begin{array}{l}\text { Good survival years = good reproduction } \\
\text { years. }\end{array}$ \\
\hline Catastrophes & No / Yes & $\begin{array}{l}\text { Drought } 10 \% \text { (negative effect on survival } \\
25 \% \text { and on reproduction } 25 \% \text { ). } \\
\text { Fire reduces reproduction by } 50 \% \text { and } \\
\text { survival by } 75 \% \text {. }\end{array}$ \\
\hline Mating system & Polygamous & \\
\hline Age at first reproduction, males & 7 years & Ben Kaddour et al., 2006 \\
\hline Age at first reproduction, females & 9 years & BEN KADDOUR et al., 2006 \\
\hline Maximum breeding age & 20 & ZNARI et al., unpublished data \\
\hline Sex ratio at birth (\% males) & $50 \%$ at $30-31^{\circ} \mathrm{C}$ & PieAu, 1975 \\
\hline Maximum clutch size per year & 7 & Ніснамі et al., 2016 \\
\hline Estimated from maximum & SCL (190 mm) & Present study \\
\hline Reproduction density-dependent? & No & Optimistic scenario \\
\hline$\%$ females breeding per year & $93.3 \%(\mathrm{EV}=0,1)$ & Diaz-Paniagua et al., 1996 \\
\hline SD breeding annually & $10 \%$ & No data available \\
\hline Clutch size & $3.3 \pm 1.7(1-5)$ & Ніснамі et al., 2016 \\
\hline Clutch size & $3.48 \pm 0.92$ & Diaz-Paniagua et al., 1996 \\
\hline Number of clutches per year & 4 & Diaz-Paniagua et al., 1996 \\
\hline Maximum number of eggs per year & 19 & Diaz-Paniagua et al., 1996 \\
\hline Mortality rate nests & $95.5 \%$ & Diaz-Paniagua et al., 1997 \\
\hline $\mathrm{SD}$ in mortality rate due to $\mathrm{EV}$ & $1.00 \%$ & EV in survival \\
\hline All adult males in the breeding pool? & Yes & Optimistic scenario \\
\hline Start at a stable age distribution? & No & Estimated from size distribution \\
\hline $\mathrm{SD}$ in $\mathrm{K}$ due to $\mathrm{EV}$ & 10 & No data available \\
\hline Trend in $\mathrm{K}$ ? & No & Optimistic scenario \\
\hline Harvest in the population? & No & \\
\hline Supplement the population & No/yes & \\
\hline
\end{tabular}


to construct realistic population viability analyses (Boyce, 1992). Thus, we firstly considered an optimistic simulation (95\% females breeding every year, no catastrophes) and carried out a sensitivity analysis. Values entered in the simulations are shown in Table 1. Density-dependent reproduction was not considered in our model, but we used a carrying capacity of $192 \pm 20$ tortoises corresponding to the highest last estimated population size (BEN KadDour et al., 2006). We ran all simulations 1000 times for 100 years.

We carried out an analysis to estimate how different management options could impact the population survival probability. We modeled the fate of the studied population, starting with a conservative scenario (Table 1). We considered a total population initial size of 88 with a known age structure (in 2012). We also tested other scenarios with different management options: a) reducing mortality of neonates and juveniles to i) $25 \%$ and ii) $50 \%$; b) two catastrophes, namely drought and bush fire (the first occurring with 0.05 annual probability, reducing reproduction and survival by $25 \%$; the second with 0.01 annual probability, reducing reproduction by $50 \%$ and survival by $75 \%$; c) supplementation (restocking) of the population during 10 years (from year 10 to 20), with 25 one-year old males and 25 one-year old females per year; d) reducing nest and neonate mortality to $90 \%$.

\section{Results}

\section{Identifying the main direct threats and their causes}

According to our study, a conceptual model of the management plan for the Souss valley tortoise T. g. soussensis in cen- tral Jbilet Mountains, west-central Morocco is summarized in Figure 1. Here, several factors are highlighted to be concerned as principal causes of threats.

These factors constitute by far the strongest threats facing the persistence of the Souss valley tortoise in west-central Morocco. There are many direct and indirect forces contributing to this threat, including, but not limited to:

a) Habitat fragmentation (e.g., railways, surfaced roads and rural paths). Potentially causes road mortality, reproductive isolation, small and discontinuous populations, and edge effects that may increase predation. Habitat destruction from activities such as urbanization and agriculture intensification, potentially causes direct mortality and/or displacement of tortoises to less favorable habitats. Habitat modification, either deliberate or not, include conversion of Jujube steppes or agricultural habitats leading to overgrazing, shrub/hardwood encroachment and establishment.

b) Over-collecting for illegal trade (see ZnARI et al., 2005; NiJMAN \& Birgin, 2017) and handling for recreational or scientific (especially during the last two decades) purposes (ZNARi \& Hichami, 2018). Handling tortoises can cause urination due to stress and then loss of precious water reserves from the urinary bladder. This leads to an acute hypo-hydration, which is a cause of mortality, particularly in juveniles.

c) Parasites, diseases and predation. Most of the tortoises we handled during the study period were infested, at various degrees, with ticks, especially Hyalonema aegyptium (Family Ixodidae). Many cases of massive infestation were observed in collected tortoises. 


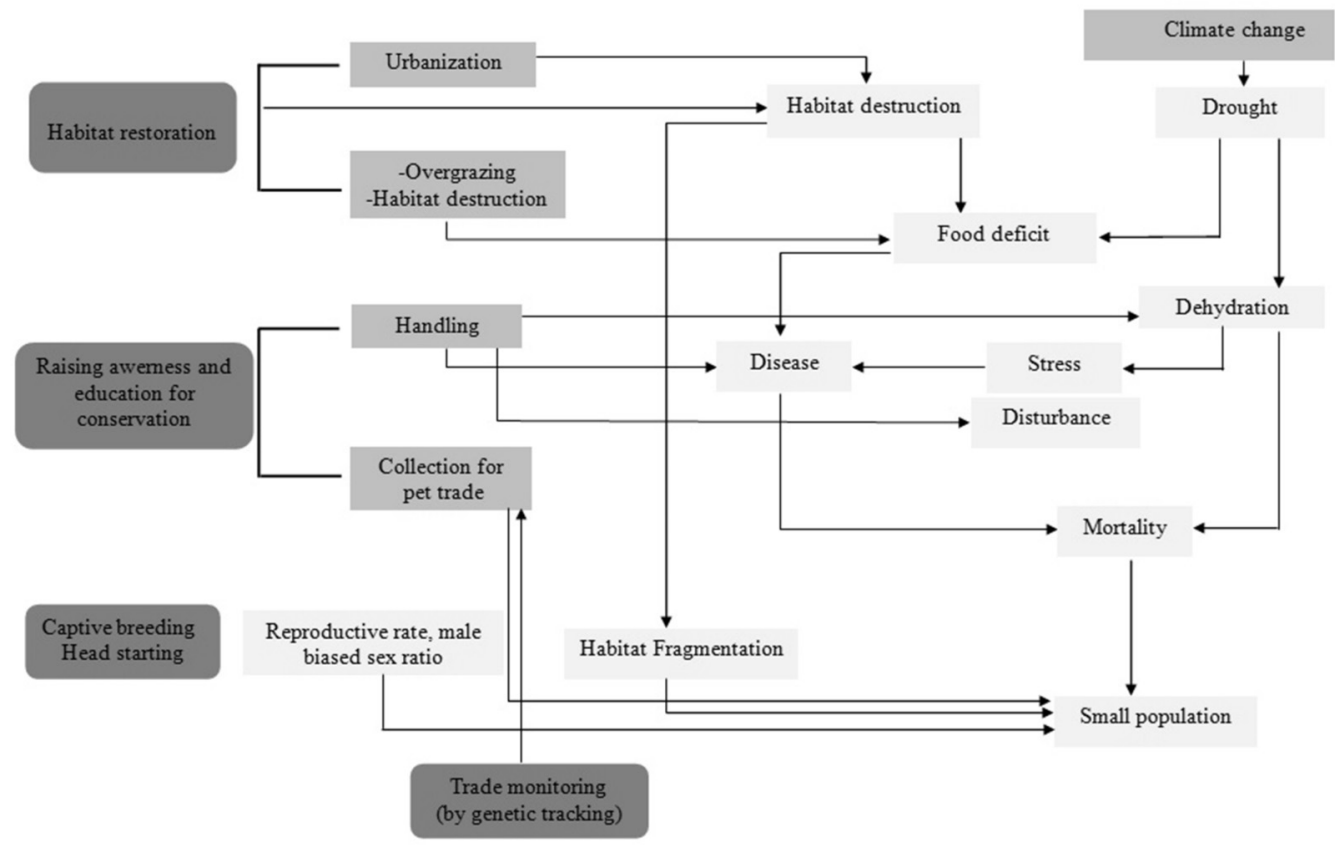

Figure 1: Conceptual model of the management plan for the Souss valley tortoise Testudo graeca soussensis in central Jbilet Mountains, west-central Morocco.

Predation, while almost exclusively to eggs, hatchlings, and small juvenile tortoises, continues to be an ever-present threat. In hatchlings, and to a lesser extent, in juveniles the shell is soft and/or not solid enough to resist to many predators such as canids, birds or even snakes.

d) Climate change. During our study period (2001-2012), the area experienced highly variable rainfall and recurrent droughts. Overall, observed climate trends in Marrakech area over the last 60 years identified a clear tendency towards higher temperatures and lower rainfall (AIT BRAHIm et al., 2017). This would affect pri- mary production and then the quality (i.e., water content and chemical composition) and availability of food resources for tortoises, which are rather specialist herbivorous feeders (El Mouden et al., 2006). This would also have a negative impact on body condition, hypo-hydration and osmotic stress (ZNARI \& Hichami, in prep.).

e) Small population size, population structure and adult annual survival rate. Seventynine individuals (including 4 juveniles, 46 adult males and 29 adult females) were tagged and then recaptured one to five times depending on each marked individual in successive sessions during the late 


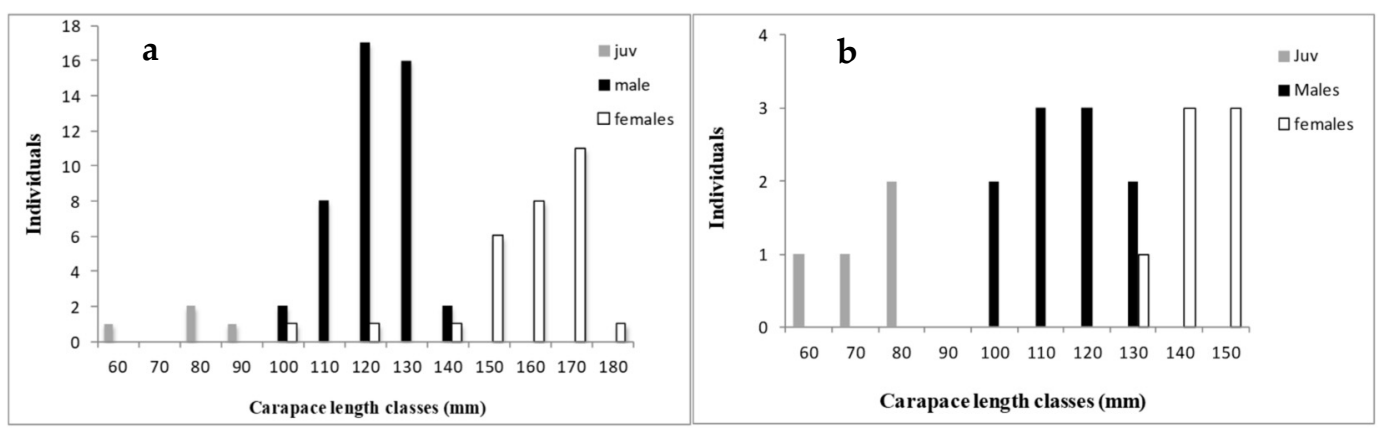

Figure 2: a) Size distribution of Testudo graeca soussensis of living individuals in the central Jbilet population, west-central Morocco; b) Size distribution of Testudo graeca soussensis of dead individuals in the Central Jbilet population, west-central Morocco. Size distributions are represented for juveniles (grey bars), adult and sub-adult females (white bars) and adult and sub-adult males (black bars).

winter-spring activity period (FebruaryMay 2012). The estimated mean total population size in spring 2012 was $88 \pm 4$ ind. (95\% confidence interval: $84-93$ ) corresponding to an average population density of 2.7 ind./ha.

The apparent frequency distribution of the captured tortoises was characterized by the scarcity of juveniles (age: 1 to 5 years), which accounted only for $5 \%$ of the total population. The majority of individuals observed were adults (95\%) with a carapace length $>100 \mathrm{~mm}$. The age-class structure among male and female subpopulations was significantly different $(\chi 2=$ $18.67, \mathrm{p}<0.05)$. Females were significantly distributed in larger classes $(\chi 2=63.4, p$ $<0.001$ ), with the largest adult female and male reaching the respective sizes of 190 and $148 \mathrm{~mm}$. The adult sex ratio is malebiased to 1.56 (61\% of males).

During the study period, juveniles, adult males and adult females represented unequal group frequencies among years $\left(\chi^{2}=36.17, \mathrm{p}<0.01\right)$. When juveniles were excluded, adult males and females were found in unequal frequencies among years $\left(\chi^{2}=3.26, p>0.05\right)$. The SCL of tortoises (including juveniles) ranged from 59 to 202 $\mathrm{mm}$. The largest male size class was 140 $145 \mathrm{~mm}$, while the largest size classes for females and juveniles were 180-185 and 59 $-90 \mathrm{~mm}$, respectively (Fig. 2a). However, except for females, SCL frequencies of each group were normally distributed $\left(\chi^{2}\right.$ $=0.198, p>0.20)$. As for dead tortoises, 21 individuals were found during the whole study period: juveniles 19\% (4 ind.), adult males $47.6 \%$ (10 ind) and adult females $33.3 \%$ (7 ind). (Fig. $2 b$ ).

Mean annual survival rates for adult male and female tortoises, estimated during the period of 2001-2012, were respectively $0.842 \pm 0.131$ (confidence interval: $0.743-0.978$ ) and $0.793 \pm 0.162$ (confidence interval: 0.634-0.987).

\section{Population viability analysis}

We carried out this analysis to estimate how different management options could 
affect the population survival probability. The results of the simulations are shown in Figure 3. We modeled the fate of the studied population in the Jbilet Mountains, starting with a conservative scenario (Table 1). We considered a total population initial size of 88 with a known age structure (in 2012). The basic scenario, with no management option, revealed that in 18 years $100 \%$ of the Jbilet population will be extinct. The model showed a high sensitivity to variations in juvenile survivorship: while a reducing mortality of juveniles by $25 \%$ showed no significant difference with the basic scenario, reducing the value to $50 \%$ delayed the extinction time to around 40 years. Similarly, the supplementation option of the population did not result in any significant improvement of the long-term maintenance probability of the population with an extinction time of slightly less than 40 years. If drought and bush fire catastrophes are considered, the population will go extinct in around 20 years, which is not different from the basic scenario and the option management of reducing juvenile mortality to only $25 \%$. On the other hand, when reducing nest mortality by $90 \%$, the probability of survival reaches $100 \%$ in 100 years.

\section{Discussion}

As indicated in Figure 1, destruction, modification, or curtailment of habitat are the axial factors responsible for the decline of the studied population of T. g. soussensis in central Jbilet Mountains, west-central Morocco. The potential causes of the aforementioned indirect effects are mainly due to the decline of available forage and groundcover (BAyley \& HighField, 1996; Lagarde et al., 2012). In addition, the loss of jujube bushes restricts the availability of thermal refuges that protect tortoises from dehydration and overheating (LAGARDE et al., 2012; Moulherat et al., 2014). In other parts of Morocco, like the Jbilet Mountains, the jujube, Z. lotus, suffers from officially promoted programs of removal. Testudo g. soussensis is threatened by such habitat loss, as tortoises must navigate between microhabitats to find essential feeding resources and thermal refuges (LAGARDe et al., 2012).

Moreover, in recent years some parts of the habitats were destroyed as a consequence of roads construction, and most of the remaining patches are heavily damaged. Some bushes that could be a good habitat for the tortoises are now separated by traffic areas. Therefore, they cannot be reached by natural dispersal. Again, an environmental education plan seems appropriate to minimize human disturbance to tortoises.

Another principal factor of the studied population decline was the over-collection for illegal trade and handling for recreational, scientific, or educational purposes. Despite legal protection under the Moroccan law (n'29-05 on the protection of wildlife and monitoring of its trade, 2011), vandalism and collection of Moorish tortoises by humans for medicinal use (NIJMIN \& BIRJING, 2017), food or as pets (ZNARI et al., 2005), were cited as threats to the species, and commercial collecting was at one time considered significant. While illegal collection of Moorish tortoises still occurs and such collection could possibly impact local populations, there is little quantitative evi- 


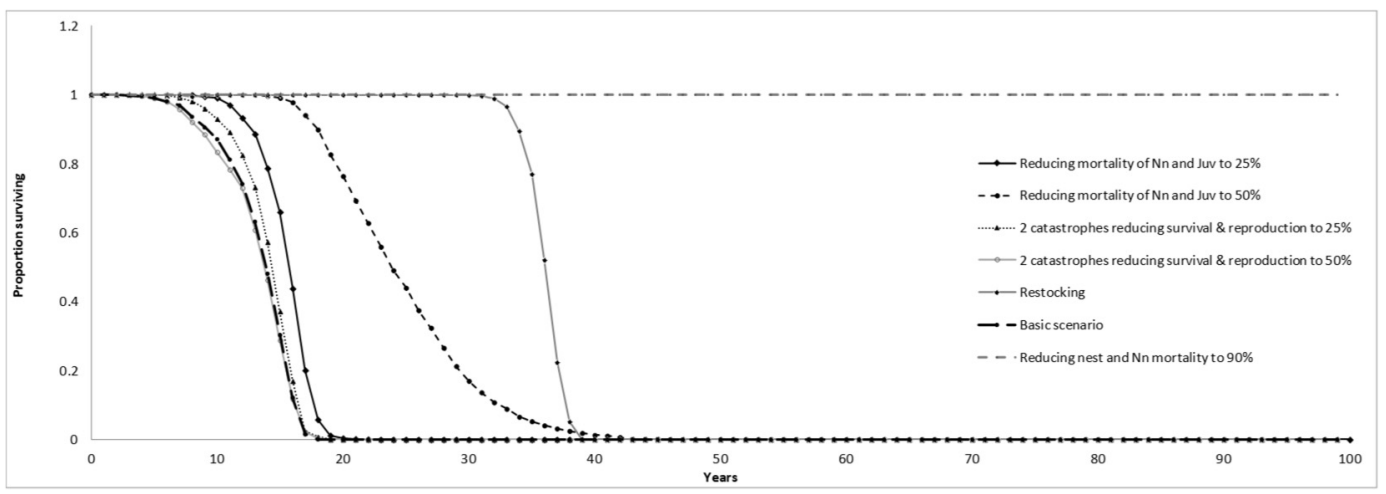

Figure 3: Results of the population viability analysis for the Souss valley tortoise population in the central Jbilet Mountains, west-central Morocco. (Nn: Neonates and juv: Juveniles).

dence specific to this threat (ZNARI et al., 2005). Hence, the impact of collecting native populations is still unknown. ZNARI et al. (2005) suggested that older, larger tortoises may have been removed in the past and now smaller tortoises are being taken. This has obvious negative consequences for these tortoise populations because not only are the large, most fecund females mostly absent, but also now the younger tortoises that could take their place are being removed. If these populations do not experience any additional collecting, particularly of younger individuals, the populations likely will be self-sustaining. However, a return to over-collecting could cause these populations to become extinct. Testudo g. soussensis may be highly sensitive to repeated illegal harvesting. Although, in certain situations (i.e., high female fecundity in a poorly degraded landscape), a moderate level of harvesting may be sustainable (Hailey, 2000). Nonetheless, LAMbert (1981) found that in North Africa, the population sizes and structures were affected by the intensive harvesting during the 1960s and 1970s.
Other potential factors are parasites, diseases and predation that are considered sources of threat for the studied population. Most of the tortoises in central Jbilet Mountains, were infested by ticks. A massive parasitism, mostly by the species $\mathrm{Hy}$ alonema aegyptum (up to 10 ticks per tortoise), the family Ixodidae, has been reported in different populations of westcentral Morocco (EL Mouden et al., 2019). These infesting ticks, were found to carry various microorganisms (KIREçCI et al., 2013). According to these authors, and in addition to various specific infections, the ticks can act as mechanical or biological vectors of different bacterial pathogens in both tortoises and humans. In addition, $92 \%$ of the tortoises from west-central Morocco were infested by gastrointestinal parasitic nematodes (LAgHzaou et al., 2021).

Several diseases have been documented in the Moorish tortoise. Free-living Moorish tortoises might suffer from upper respiratory tract disease (URTD), a pathology primarily caused by Mycoplasma agassizii (Lecis et al., 2011). In addition, Salmo- 
nella bacteria were found in almost $90 \%$ of tortoises from central Jbilet Mountains (Hidalgo-Vila et al., 2008). In terrestrial chelonians, Salmonella species are considered part of the intestinal flora, and do not cause any clinical signs. However, in immune-compromised animals, they may cause salmonellosis, an important reptilian zoonosis.

Predation on hatchling and juveniles of T. graeca has already been documented for several birds and mammals (SCHLeich et al., 1996; Geffen \& Mendelssohn, 1997; KeLLER et al., 1998). Many predators might potentially have an impact that has not been fully documented. Predators include feral dogs, foxes, raptors, and other species. In west central Morocco, hatchlings of T. g. soussensis were found impaled by the Grey Shrike Lanius meridionalis, on spiny shrubs and Argan trees Argania spinosa (BARJE et al., 2005).

Climate change is a major factor to be taken into account in the studied population decline. Increasing environmental temperature and reduced precipitation would negatively impact the primary productivity and water availability in the steppe ecosystem, which in turn will affect tortoise biology and ecology (i.e., thermal regulation: LAGARDE et al. (2012), and osmoregulation: НiснамI (2017); unpublished data). Climate change would also directly or indirectly affect some other causes of population regression. In such situation of aridification, tortoises will be more subjected to tissue hypo-hydration and osmotic stress, and general weakening related to nutritional deficiencies due to lower primary production and plant quality (Znari \& Hichami, in prep.). Hypohy- drated tortoises reach a critical threshold that is fatal to them from diseases due to increased susceptibility to pathogens and parasites associated with a deficiency of the immune system. The studied inland populations of west-central Morocco occur at the southern distribution limit of $T$. graeca in Morocco (Anadon et al., 2012). Here, high temperatures are very common in spring, suggesting that climate may favor the production of more females. Also, potential differences in mortality and emigration rates between sexes could be involved.

The studied population of $T . g$. soussensis in central Jbilet Mountains, suffers from other main problems: the population size is quite small, the adult sex ratio is male-biased (61:39) and the hatchling/juvenile mortality is probably very high (based on the very low proportions of these classes in the population). About ten years before, ZNARI et al. (2005) and Ben Kaddour et al. (2006) reported, respectively in spring 2001 and 2003, a balanced sex ratio for this same population in the Jbilet Mountains. We are confident that our sampling is not male-biased; both males and females were searched for at the same time with the same capture effort; catching was rather exhaustive. Thus, the recorded sex ratio is the real sex ratio of the population, and males outnumber females indeed.

The age-class distribution observed in our study population shows a pattern typical for chelonian populations (Stuвbs et al., 1985, Stubbs \& Swingland, 1985; Ben Kaddour et al., 2006), including other studied T. graeca populations (Braza et al., 1981; Lambert, 1982; Andreu et al., 2000; 
Diaz-Paniagua et al., 2001a,b). Notably, most of the individuals that were collected during the study period (including all seasons) were adults or sub-adults, juveniles being almost inconspicuous. BEN KADDOUR et al. (2006) previously reported a similar distribution for the same population in Central Jbilet Mountains. Such a distribution highly biased towards older individuals may be interpreted as an indicator of a low reproductive rate related to severe population dynamic problems such as a lack of generation renewal (Stubbs \& Swingland, 1985). Ben Kaddour et al. (2006) suggested that such a pattern could be exacerbated by the very low catchability of juveniles as observed in many reptiles (Madsen \& Shine, 2000; Nagy, 2000). Juveniles are under strong selection to reach sexual maturity; they remain very cryptic and very hard to find whereas adults exhibit a more conspicuous lifestyle, especially during sexual activities (LAgarde et al., 2001). Considering the size distribution of animals found dead in the field, Ben Kaddour et al. (2006) confirmed the occurrence of the "missing" juvenile class representing $64 \%$ of the total dead tortoises. In the present study, this class was also found, but was much less represented (only $19 \%$ of the dead tortoises collected).

We suggest an environmental education plan to minimize all these threats. Testudo g. soussensis is still captured as a pet, despite being illegal. Furthermore, most of the individuals from the Central Jbilet population have been illegally collected. In addition, handling tortoises for research or recreational activities may induce urination (loss of water reserve in the bladder) due to stress and this can have a negative impact on tortoises during drought periods (Znari \& Hichami, in prep.).

The population size estimate in the central Jbilet Mountains was of 192 adults and sub-adults in spring 2003 (Ben Kaddour et al., 2006), which corresponds to a population density of about 6 ind./ha. In spring 2012 (the present study), the population size estimate was only 88 adults and subadults corresponding to a halved population density ( 3 ind./ha) in less than 10 years. Nevertheless, the estimated tortoise's density is relatively close to those reported in Algeria ( 4 ind./ha, RouAg et al., 2007) and Southern Spain (1.7 to 4.2 ind/ha, BrAzA et al., 1981, ANDreu 1987, ANDREu et al., 2000).

All the above-mentioned threats and their combination will cause higher mortality rates and a population decline and extinction.

Stochastic demographic processes might be combined to increase extinction probability in small populations. Also, the number of females is relatively low, which might be imputed to a higher mortality rate in females. If a higher adult female mortality occurs in our population, then we would expect females to be rarer among mature age classes. Our data seem in favor of this hypothesis: females are rare among young individuals. Our results suggest a greater mortality of juveniles and young adult females as causes for the male-biased adult sex ratio, rather than a male-biased hatchling sex ratio. This could be partially corrected by captive breeding and the supplementation of the population with more females than males (Vogt, 1994). Nevertheless, our simulations do 
not suggest the release of hatchlings to be a good management measure. In addition, head starting could be a good management tool for long-lived animals, as adult mortality remains very low.

The maintenance of viable populations of the Souss valley tortoise in west-central Morocco is also dependent on an ecological restoration of the population and its natural habitat. Our population viability analysis suggests that the crucial management measures are reducing juvenile mortality and restocking based on a headstarting program. Creating a reserve in this area and talking to local people to convince them to stop collecting tortoises could be helpful. Reducing the effect of chronic drought (especially during summer), could be achieved by constructing drinkers and replanting new jujubes. Supplementing the population with captivebred and head-started tortoises seems to be a good strategy, but not if the juvenile mortality remains high. However, this activity might have important social effects and could be important for environmental education. Avoiding catastrophes, namely fire, and bush destruction and overgrazing by protecting habitats, is needed to minimize threats. Finally, given the deterministic nature of habitat destruction, measures to correct these problems are a priority. Therefore, we suggest that a project of ecological restoration of steppe-lands is the most important component of the management plan for this population. In Morocco, and as stated before, one of the main bush species in arid areas, the jujube (Z. lotus), suffers from officially promoted removal programs. Testudo g. soussensis is threatened by such habitat loss. Tortoises are forced to move between microhabitats looking for essential food resources and thermal refuges (Lagarde et al., 2012). These authors reported that the occurrence of tortoises is related to that of large and relatively abundant bushes to avoid deathful overheating. Jujube bushes, including the larger ones with tortoises, are over harvested and often cut to the ground and their growth rate is very slow due to the combined effects of regular droughts and overgrazing (LAgarde et al., 2012). Therefore, the current officially encouraged destruction of jujube bushes need to be substantially limited. Habitat restoration consisting of replanting jujube bush should be favorized. Large-scale monitoring of critical bush densities is necessary for better organizing conservation plans (protection and/or restoration of habitats) for Souss valley tortoise. Finally, construction of small natural reserves, reinforcing and connecting populations through replanting, and a better protection of jujube bushes could considerably improve local habitats in such arid areas.

We concluded that two major factors are deterministic for the long-term persistence of the central Jbilet tortoise population: i) high nest and juvenile mortality, and ii) climatic conditions, especially long drought periods. Therefore, we suggest that Captive breeding and Head-Starting would be the most significant components of the management plan of this threatened population. In addition, a project of ecological restoration of steppe-lands would enhance the tortoise survival in these degraded and overgrazed arid areas of westcentral Morocco. 


\section{Acknowledgement}

We are very indebted to all $\mathrm{PhD}$ students who helped during the field and/or laboratory works, with a special thanks to the inhabitants of Douar (small village) Salas. We would like to thank the British Ecological Society, UK for the grant they provided for our research on the Souss valley tortoise in the central Jbilet Mountains.

\section{REFERENCES}

Ait Brahim, Y.; Saidi, M.E.; Kouraiss, K.; SifedDinE, A. \& Bouchaou, L. (2017). Analysis of observed climate trends and high-resolution scenarios for the $21^{\text {st }}$ century in Morocco. Journal of Materials and Environmental Sciences 8: 1375-1384.

Anadón, J.D.; Giménez, A.; Graciá, E.; Pérez, I.; FerRández, M.; FAHD, S.; EL Mouden, E.H.; Kalboussi, M.; Jdeidi, T.; Larbes, S.; RouaG, R.; Slimani, T.; Znari, M. \& Fritz, U. (2012). Distribution of Testudo graeca in the Western Mediterranean according to climatic factors. Amphibia-Reptilia 33: 285-296.

Andreu, A.C. (1987). Ecología y dinámica poblacional de la tortuga mora, Testudo graeca, en Doñana. Ph.D. Dissertation, University of Sevilla, Sevilla, Spain.

Andreu, A.C.; Diaz-Paniagua, C. \& Keller, C. (2000). La Tortuga Mora Testudo graeca en Doñana. Monografías de Herpetología, vol. 5. Asociación Herpetológica Española, Barcelona, Spain.

Barje, F.; Slimani, T.; El Mouden, E.H.; Lagarde, F.; Bonnet, X. \& Ben Kaddour, K. (2005). Shrewd shrikes and spiny shrubs: a calamity for hatchling Moorish tortoises (Testudo graeca graeca). Amphibia-Reptilia 26: 113-115.

Bayley, J.R. \& Highfield, A.C. (1996). Observations on ecological changes threatening a population of Testudo graeca graeca in the Souss Valley, Southern Morocco. Chelonian
Conservation and Biology 2: 36-42.

Ben Kaddour, K.; Slimani, T.; El Mouden, E.H.; Lagarde, F. \& Bonnet, X. (2006). Population structure, population density and individual catchability of Testudo graeca in the central Jbilet (Morocco). Vie et Milieu 56: 49-54.

Boarman, W.I. (2003). Managing a Subsidized Predator Population: Reducing Common Raven Predation on Desert Tortoises. Environmental Management 32: 205-217.

Boyce, M.S. (1992). Population viability analysis. Annual Review of Ecology, Evolution, and Systematics 23: 481-506.

Braza, F.; Delibes, M. \& Castroviejo, J. (1981). Estudio biometrico y biologio de la tortuga mora (Testudo graeca) en la reserva biologica de Doñana, Huelva. Doñana Acta Vertebrata 8: 15-41.

Соосн, E. \& White, G. (2001). Program MARKA Gentle Introduction, $2^{\text {nd }}$ ed. Analysis of data from marked individuals. www.phidot.org, Fort Collins, Colorado, USA.

Diaz-Paniagua, C.; Keller, C. \& Andreu, A.C. (1995). Annual variation of activity and daily distances moved in adult Spur-thighed tortoises, Testudo graeca, in southwestern Spain. Herpetologica 51: 225-233.

Diaz-Paniagua, C.; Keller, C. \& Andreu, A.C. (1996). Clutch frequency, egg and clutch characteristics, and nesting activity of Spurthighed tortoises, Testudo graeca, in southwestern Spain. Canadian Journal of Zoology 74, 560-564.

Diaz-Paniagua, C.; Keller, C. \& Andreu, A.C. (1997). Hatching success, delay of emergence and hatchling biometry of the Spurthighed tortoise, Testudo graeca, in southwestern Spain. Journal of Zoology 243: 543553.

Diaz-Paniagua, C.; Keller, C. \& Andreu, A.C. (2001a). Long-term demographic fluctuations Spur-thighed tortoise Testudo graeca in SW Spain. Ecography 24: 707-721.

Diaz-Paniagua, C.; Keller, C. \& Andreu, A.C. (2001b). Life history and demography of 
Testudo graeca in southwestern Spain. Chelonii 3: 214-222.

Doak, D.; Kareiva, P. \& KlepetKa, B. (1994). Modeling Population Viability for the Desert Tortoise in the Western Mojave Desert. Ecological Applications 4: 446-460.

El Mouden, E.H.; Slimani, T. \& Ben Kaddour, K. (2002). Croissance et dimorphisme sexuel chez la Tortue Mauresque (Testudo graeca graeca L., 1758). Chelonii 3: 325-330.

El Mouden, E.H.; Znari, M. \& Brown, R. (1999). Skeletochronology and mark recapture assessments of growth in the North African agamid lizard (Agama impalearis). Journal of Zoology of London 249: 455-461.

El Mouden E.; Laghzaoui E.; Elbahi A. \& АвBAD, A. (2019). A case of massive infestation of a female Spur-thighed tortoise Testudo graeca by blood-sucking ticks Hyalomma aegyptium (Acari: Ixodidae). International Journal of Acarology 46: 1-3.

Emberger, L. (1933). Nouvelle contribution à l'étude de la classification des groupements végétaux. Revue Générale de Botanique 45: 473 $-486$.

Ernst, C.H. \& Barbour, R.W. (1989). Turtles of the World. Smithsonian Institution Press, Washington, DC, USA.

Hailey, A. (1988). Population ecology and conservation of tortoises: the estimation of density and dynamics of a small population. Herpetological Journal 1: 263-271.

Hailey, A. (1990). Adult survival and recruitment and the explanation of an uneven sex ratio in a tortoise population. Canadian Journal of Zoology 68: 547-555.

Hailey, A. (2000). Implications of high intrinsic growth rate of a tortoise population for conservation. Animal Conservation 3: 185-189.

Hailey, A.; Wright, J. \& Steer, E. (1988). Population ecology and conservation of tortoises: the effect of disturbance. Herpetological Journal 1: 294-301.

Hidalgo-Vila, J.; Diaz-Paniagua, C.; Ruiz, X.; Portheault, A.; El Mouden, E.H.; Slimani,
T.; Frutos-Escobar, C. \& DeCaso, M.S. (2008). Salmonella in free-living Spurthighed (Testudo graeca) from Central Western Morocco. Veterinary Record 162: 218-219.

Hulin, V.; Delmas, V.; Girondot, M.; God-frey, M. H. \& Guillon, J. M. (2009). Temperature dependent sex determination and global change: are some species at greater risk? Oecologia 160: 493-506.

Iverson, J.B. (1992). A Revised Checklist with Distribution Maps of the Turtles of the World. J. P. Iverson Publishing. Richmond, Indiana, USA.

Keller, C. (1993). Use of fluorescent pigment for tortoise nest location. Herpetological Review 24: 140.

Keller, C.; Diaz-Paniagua, C. \& Andreu, A.C. (1998). Survival rates and causes of mortality of Testudo graeca hatchlings in southwestern Spain. Journal of Herpetology 32: 238-243.

Lagarde, F.; Louzizi, T.; Slimani, T.; EL Mouden, E.H.; Ben Kaddour, K. Moulherat, S. \& BonnET, X. (2012). Bushes protect tortoises from lethal overheating in arid areas of Morocco. Environmental Conservation 39: 172182.

Laghzaou E.; Amahmid O.; Abbad, A. \& El Mouden E. (2021). Prevalence and intensity of gastro intestinal parasites in the vulnerable spur-thighed tortoise (Testudo graeca) from the central-western of Morocco. Basic and Applied Herpetology 35: 63-75.

Lambert, M.R.K. (1969). Tortoise drain in Morocco. Oryx 10: 161-166.

LAmbert, M.R.K. (1981). Temperature, activity and field sighting in the Mediterranean Spur -thighed or common garden tortoise, Testudo graeca. Biological Conservation 21: 39-54.

LAMbERT, M.R.K. (1982). Studies on the growth, structure and abundance of the Mediterranean spur-thighed tortoise, Testudo graeca, in field populations. Journal of Zoology 196: 165189.

LAMberT, M.R.K. (1995). Tortoise situation in northern Africa, In D. Ballasina (ed.) Red 
Data Book on Mediterranean Chelonians. Edagricole, Bologna, Italy, pp. 1-19.

Lambert, M.R.K. (1979). Trade in Mediterranean tortoises. Oryx 15: 81-82.

Le Houérou, H. (1989). Classification éco climatique des zones arides (s.l.) de l'Afrique du Nord. Ecologia Mediterranea 15: 95-144.

Lebreton, J.D.; Burnham, K.P.; Clobert, J. \& Anderson, D.R. (1992). Modelling survival and testing biological hypotheses using marked animals: a unified approach with case studies. Ecological Monographs 62: 67118.

Lecis, R.; Paglietti, B.; Rubino, S.; Are, B.M.; Muzzeddu, M.; Berlinguer, F.; Chessa, B.; Pittau, M. \& Alberti, A. (2011). Detection and characterization of Mycoplasma sp. and Salmonella sp. in free-living European tortoises (Testudo hermanni, Testudo graeca, and Testudo marginata). Journal of Wildlife Diseases 47: 717-724.

Madsen, T. \& Shine, R. (2000). Restoration of an inbred adder population. Nature 402: 34-35.

Miller, P.S. \& LACY, R.C. (2005). VORTEX: A Stochastic Simulation of the Extinction Process. Version 9.50 User's Manual. Conservation Breeding Specialist Group (SSC/IUCN), Chicago, Illinois, USA.

NAGY, K.A. (2000). Energy costs of growth in neonate reptiles. Herpetological Monographs 14: 378-387.

Pérez, I.; Giménez, A. \& Pedreno, A. (2011). A qualitative examination of the social practices and representations towards a species of endangered tortoise. Wildlife Research 38: 323 -329 .

QuÉzel, P. (2002). Réflexions sur l'Évolution de la Flore et de la Végétation au Maghreb Méditerranéen. Ibis Press, Paris, France.

Rouag, R.; Benyacoub, S.; Luiselli, L.; El mouden, E.H.; Tiar, G. \& Ferrah, C. (2007). Population structure and demography of an Algerian population of the Moorish tortoise, Testudo graeca. Animal Biology 57: 267-279.

Schleich, H.H.; Kästle, W. \& Kabisch, K. (1996).
Amphibians and Reptiles of North Africa: Biology, Systematics, Field Guide. Koeltz Scientific Books, Oberreifenberg, Germany.

Schwartz, T.S. \& KarL, S. A. (2006). Population and conservation genetics of the gopher tortoise (Gopherus polyphemus). Conservation Genetics 6: 917-928.

Shine, R. \& Iverson, J.B. (1995). Patterns of survival, growth and maturation in turtles. Oikos 72: 343-348.

Slimani, T.; El Mouden, E.H. \& Ben Kaddour, K. (2002). Structure et dynamique d'une population de Testudo graeca graeca L.1758 dans les Jbilet Centrales, Maroc. Chelonii 3: 200-207.

StubBs, D. (1989). Tortoises and Freshwater Turtles: An Action Plan for their Conservation. IUCN/SSC Tortoise and Fresh water Turtle Specialist Group, Canterbury, UK.

Stubbs, D.; Swingland, I.R. \& Hailey, A. (1985). The ecology of the Mediterranean tortoise Testudo hermanniiin northern Greece (the effects of a catastrophe on population structure and density). Biological Conservation 31: 125-152.

Sutherland, W.J. (1996). Ecological Census Techniques: A Handbook. Cambridge University Press, Cambridge, UK.

Van Abbema, J. (1997). Conservation, Restoration, and Management of Tortoises and Turtles. Proceedings of the International Conference of the New York Turtle \& Tortoise Society. York Turtle \& Tortoise Society, New York, USA.

Vogt, R.C. (1994). Temperature controlled sex determination as a tool for turtle conservation. Chelonian Conservation Biology 1: 159162.

Znari, M.; El Mouden, E.H. \& FrancillonVieillot, H. (2002). Long-term variation in reproductive traits of Bibron's Agama, Agama impalearis, in Western Morocco. African Journal of Herpetology 51: 57-68.

Znari, M.; Germano, D.J. \& Macé, J.C. (2005). Growth and population structure of the Moorish Tortoise (Testudo graeca graeca) in West central Morocco: Possible effects of 
over collecting for the tourist trade. Journal of Arid Environments 62: 55-74.

Znari, M. \& Hichami, N. (2018). Biology, Life History Traits and Conservation of the Vulnerable Souss Valley Tortoise in Arid Areas of West Central Morocco. IntechOpen, London, UK. Available at: https:// www.intechopen.com/chapters/61462. Retrieved on 31 March 2020. 